\title{
TUMBLEWEED AND CHEATGRASS UPTAKE \\ OF TRANSURANIUM ELEMENTS APPLIED \\ TO SOIL AS ORGANIC ACID COMPLEXES
}

Keith R. Price

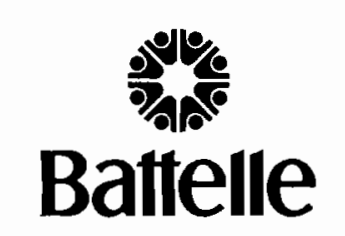

Pacific Northwest Laboratories

Richland, Washington 99352

MAY 1973

Prepared for the U.S. Atomic Energy

Commission under Contract AT(45-1):1830 


\section{NOTICE}

This report was prepared as an account of work sponsored by the United States Government. Neither the United States nor the United States Atomic Energy Commission, nor any of their employees, makes any wardanty, express or implied, or assumes any legal liability or responsibility for the accuracy, completeness or usefulness of any information, apparatus, product, or process disclosed, or represents that its use would not infringe privately-owned rights.

PACIFIC NORTHWEST LABORA TORY

operated by

BATTELLE

for the

U.S. ATOMIC ENERGY COMMISSION

Under Contract AT(45-1)-1830

AEC.RL RICHLAND. WASH 
BNWL- 1755

Special Distribution

\section{TUMBLEWEED AND CHEATGRASS UPTAKE OF TRANSURANIUM}

ELEMENTS APPLIED TO SOIL AS ORGANIC ACID COMPLEXES

Keith R. Price

Ecosystems Department

May 1973

This report is based on work sponsored by the Atlantic Richfield Hanford Company under United States Atomic Energy Commission Contract AT(45-1)-2130

BATTELLE

PACIFIC NORTHWEST LABORATORIES

RICHLAND, WASHINGTON 99352 
BNWL -1755

\section{FOREWORD}

This is an interim report of work in progress. The results reported are of a preliminary nature, and interpretation may be modified in the light of subsequent data. 


\section{CONTENTS}

Foreword. . . . . . . . . . . . . i i

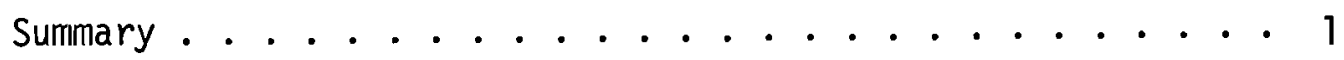

Introduction. ................ 2

Materials and Methods............. 4

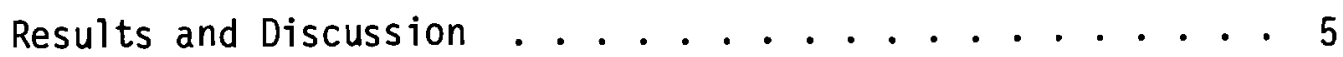

Acknowledgments ................ 9

Literature Cited. . . . . . . . . . . 10

\section{$\underline{\text { TABLES }}$}

Table 1. Initial pH of Soil Following the Addition of Spiked Solutions. Soll pH's are of saturation pastes of air-dried treated soil. Original soil pH was $7.8 \ldots \ldots . \ldots 7$

Table 2. Concentration Factors for Tumbleweed and Cheatgrass Shoot Uptake. Transuranics were added to soil in dilute nitric acid or as complexes of the organic acids indicated ........ 8 


\section{SUMMARY}

Plant uptake of radioactive waste materials is a biological interaction important to the environmental management of waste storage sites. This study on the uptake of transuranium elements from soil by plants demonstrates that shoot uptake is clearly influenced by the chemical form of the transuranic. It is unclear at this time whether soil or plant mechanisms, or both, are responsible. Future studies are planned to investigate these aspects. The observation that some organic acids suppress plant uptake of americium and curium will be investigated further to evaluate the use of soil additives to suppress plant uptake of transuranics. Test results indicate that organic acid complexes of plutonium such as oxalate or citrate can increase plant uptake when added to soil as compared to uptake from dilute nitric acid solutions. 


\section{INTRODUCTION}

The transfer of materials from soils into plants is a biological interaction with nuclear wastes important to the environmental management of waste storage sites. Price ${ }^{(1)}$ reported previously that plant uptake of transuranium elements added to soil in dilute nitric acid solutions was rather large for ${ }^{237} \mathrm{~Np}$ ( $2 \%$ of application), small for ${ }^{241} \mathrm{Am}$ or ${ }^{244} \mathrm{Cm}$ ( $<0.05 \%$ of application) and slight for ${ }^{239} \mathrm{Pu}(<0.001 \%$ of application). These determinations serve as base cases; however, transuranics at waste storage sites probably do not occur only as simple ions or nitrate complexes. More likely, these heavy elements would form chemical complexes with other materials common to the waste streams. Various kinds of chemical complexing agents have been used in nuclear fuel processing and associated operations, but the possibility of such waste chemicals acting to erhance or suppress biological availability of radionuclides has not been previously studied.

The formation of complexes between organic compounds and actinide elements has been intensively studied in the search for new plutonium processing methods. The subject has been reviewed by Gel'man et al., (2) and Coleman. (3) Research findings show that complex formation with organic acids generally occurs under conditions of low solution concentrations and high organic acid-to-element ratios. In the absence of organic acids or other complexing agents and at low acidity, actinides polymerize with the hydrolysis products of water and form insoluble hydroxy - or oxoradiocolloids. However, complexes formed with organic acid ligands are quite stable and effectively increase the solubility of actinides in aqueous media. Increased mobility of transuranium elements due to complexation with organic acids has been shown previously to occur in soil systems. Rhodes ${ }^{(4)}$ and $\mathrm{Knoll}^{(5)}$ reported the mobility of Pu or Am in soil to be increased significantly in the presence of organic acid ligands. It is generally held that factors increasing the water solubility of heavy elements can be expected to increase their uptake from soil by plants. However, it is also possible that plant roots or other tissues are impermeable to some transuranium element complexes and plant uptake would 
effectively be suppressed. Thus, the objective of this study is to determine plant uptake of transuranium elements when added to soil as organic acid complexes. These data are compared to the previous study on plant uptake where transuranics were added to soil in dilute solutions of nitric acid. ${ }^{(1)}$ 


\section{MATERIALS AND METHODS}

Materials and methods used in this study as well as the physical and chemical properties of the test soil were previously detailed. (1) The soil used was Burbank loamy sand, a calcareous loamy sand characteristic of top soils at Hanford waste storage sites. It has a low cation exchange capacity ( $26 \mathrm{meq} / 100 \mathrm{~g}$ ) and poor nutritional quantities. Pots containing $1 \mathrm{~kg}$ of soil were irrigated frequently with distilled water and about $170 \mu \mathrm{g} \mathrm{N} / \mathrm{g}$ soil were added as $\mathrm{NH}_{4} \mathrm{NO}_{3}$. The test plants were tumbleweed (Salsola kali) and cheatgrass (Bromus tectorum). Planting, culturing, and harvesting were the same as used previously. Analytical techniques also were the same and involved ashing, aliquoting, and liquid scintillation counting.

Dilute solutions (0.15M) of the salts of organic acids were prepared and spiked to approximately $2.5 \mu \mathrm{Ci} / \mathrm{ml}$ of ${ }^{237} \mathrm{~Np},{ }^{241} \mathrm{Am}$ and ${ }^{244} \mathrm{Cm}$ or about $5 \mu_{\mathrm{C}} \mathrm{i} / \mathrm{ml}$ of ${ }^{239} \mathrm{Pu}$. The organic acids used were:

$\begin{array}{lll}\text { acetate } & \text { as } & \mathrm{NH}_{4} \mathrm{C}_{2} \mathrm{H}_{3} \mathrm{O}_{2} \\ \text { glycolate } & \text { as } & \mathrm{NaC}_{2} \mathrm{H}_{3} \mathrm{O}_{3} \\ \text { oxalate } & \text { as } & \left(\mathrm{NH}_{4}\right)_{2} \mathrm{C}_{2} \mathrm{O}_{4} \\ \text { citrate } & \text { as } & \left(\mathrm{NH}_{4}\right)_{2} \mathrm{HC}_{5} \mathrm{H}_{5} \mathrm{O}_{7} .\end{array}$

The molar ratios of organic acid salts to radionuclides were:

neptunium-237 81

$\begin{array}{ll}\text { plutonium-239 } & 2.7 \times 10^{3} \\ \text { americium-241 } & 3.2 \times 10^{5} \\ \text { curium-244 } & 8.0 \times 10^{6}\end{array}$

The increase in molar ratio value is mostly due to an increase in specific activity of the nuclides as they are listed. The half-life of ${ }^{237} \mathrm{~Np}$ is very long $\left(2.14 \times 10^{6} \mathrm{y}\right)$, whereas that for ${ }^{244} \mathrm{Cm}$ is comparatively short $(18.1 \mathrm{y})$. Approximately $10 \mathrm{ml}$ aliquots of spiked solutions were uniformly added to the soil surfaces of three replicate pots. After the solutions had dried, a $1 \mathrm{~cm}$ layer of soil was added and seeds were planted into the untreated soil. Plants were grown in a growth chamber for 2 months. 


\section{RESULTS AND DISCUSSION}

Transuranium elements normally react with a host of ligands which result in the formation of chemical complexes. Polymerization also is common under appropriate conditions and in the absence of complexing ligands is the form of plutonium suspected in an aqueous environment. Information discussed by Gel'man et al. ${ }^{(3)}$ indicates the tendency for the transuranic cations used in this study to form complexes is in the order $\mathrm{Pu}^{+4}>\mathrm{Cm}^{+3} \simeq \mathrm{Am}^{+3}>\mathrm{NpO}_{2}^{+}$. Citrate is expected to form complexes with these transuranics more readily than the other organic salts used because it has the greatest number of coordination positions. Gel'man et a1. indicate that at molar ratios of $>4: 1$ citrate: $\mathrm{Pu}$ and at $\mathrm{pH}$ 's of $>5$, complex formation should be complete. Similar results are expected with the other transuranics used and for oxalate. There is little information on acetate and glycolate except that complexes probably do exist under appropriate conditions.

The pH's of the treatment soils following the addition of organic acid complex solutions are given in Table 1. The nitrate series is of an experiment previously reported ${ }^{(1)}$ and is listed here for purposes of comparison. The preparation of small quantities of transuranic complexes with organic acids is difficult at best. To avoid complications brought on by neutralization of transuranic solutions, all organic acids of a given series were spiked with the same amount of transuranic. The initial $\mathrm{pH}$ of all complex treatment soils, except for the Np series, is greater than the original $\mathrm{pH}$ of 7.8. It should be emphasized that the $\mathrm{pH}^{\prime} \mathrm{s}$ listed in Table 1 represent a smal1 layer of soil (about $5 \mathrm{~mm}$ ) within the pot. Changes in $\mathrm{pH}$ within this layer with time and during plant growth and the influence on plant uptake of contaminated soil layers at different $\mathrm{pH}^{\prime} \mathrm{s}$ are subjects of further research in progress. However, it is suspected that initial soil pHs' are not particularly influential to plant uptake or that any influence is masked by a much larger influence due to complexation. For example, no $\mathrm{pH}$ dependent relationship is obviated when uptake data in Table 2 are plotted as a function of the initial soil pH for that treatment. 
Concentration factors for plant shoot uptake of transuranics added to soil as complexes are presented in Table 2 and compared with uptake from nitrate forms. Uptake from nitrate forms is in reverse order of the tendency of the transuranics to form complexes or to undergo cation hydrolysis and eventually polymerize. Plant uptake of the transuranics added to the soil as organic acid complexes was in the same order as uptake from nitrate, i.e., $\mathrm{Np}>\mathrm{Cm} \simeq \mathrm{Am}>\mathrm{Pu}$. The effect of chemical form is evident. Neptunium-237 and ${ }^{239} \mathrm{Pu}$ uptake from complexes genera) 1y was greater than uptake from nitrate, whereas, uptake from ${ }^{241} \mathrm{Am}$ and ${ }^{244} \mathrm{Cm}$ complexes was less than from nitrate forms. Thus, the order of uptake compared among transuranics was unchanged, but uptake compared among chemical forms varied with the kind of transuranic and complexing agent used. Transuranics with oxidation state of IV or V ( $\mathrm{Pu}$ and $\mathrm{Np}$, respectively) generally showed increased uptake with complexation, and the III elements (Am and $\mathrm{Cm}$ ) showed little change or a decreased uptake relative to nitrate forms. Glycolate, oxalate, and citrate complexes enhanced ${ }^{239} \mathrm{Pu}$ uptake by tumbleweed or cheatgrass. The enhancement with citrate was more than sixfold for tumbleweed. Americium-241 and ${ }^{244} \mathrm{Cm}$ complexes of these organic acids resulted in decreased tumbleweed or cheatgrass uptake compared to nitrate forms. Americium-241 uptake by cheatgrass from the oxalate treatment was reduced by 10-fold compared to uptake from the nitrate form. Differences in uptake between the species used as test plants frequently amounted to more than 10-fold. Results show that the chemical form of ${ }^{237} \mathrm{~Np},{ }^{239} \mathrm{Pu},{ }^{241} \mathrm{Am}$ and ${ }^{244} \mathrm{Cm}$, at the time of their addition to soil, influences plant uptake of these radioelements. When added to soil as organic acid complexes, $\mathrm{plant}$ uptake of $\mathrm{Np}$ and $\mathrm{Pu}$ was generally increased compared to uptake from nitrate forms. Americium and $\mathrm{Cm}$ uptake, however, was decreased. It is unclear at this time whether soil or plant mechanisms, or both, are responsible. The effects of varying the $\mathrm{pH}$ of the spiked treatment solution will be investigated. The distribution of radioelement within the plant (e.g., root/shoot ratios) will be determined as a function of initial chemical form. The use of soil additives to suppress plant uptake also will be investigated. 
TABLE 1. Initial pH of Soil Following the Addition of Spiked Solutions. Soil pH's are of saturation pastes of air-dried treated soil. Original soil pH was 7.8.

\begin{tabular}{|c|c|c|c|c|c|}
\hline & Nitrate & Acetate & Glycolate & Oxalate & Citrate \\
\hline${ }^{237} \mathrm{~Np}$ & 5.1 & 7.4 & 6.6 & 6.5 & 6.8 \\
\hline${ }^{239} \mathrm{Pu}$ & 5.1 & 8.5 & 9.1 & 8.6 & 8.3 \\
\hline${ }^{241}$ Am & 5.1 & 8.0 & 8.9 & 8.4 & 8.1 \\
\hline${ }^{244} \mathrm{Cm}$ & 5.1 & 8.5 & 9.1 & 8.6 & 8.3 \\
\hline
\end{tabular}


TABLE 2. Concentration Factors (a) for Tumbleweed and Cheatgrass Shoot Uptake. Transuranics were added to soil in dilute nitric acid or as complexes of the organic acids indicated.

Tumbleweed

\begin{tabular}{|c|c|c|c|c|c|}
\hline & ritrate ${ }^{(b)}$ & Acetate & Glycolate & Oxalate & Citrate \\
\hline $237 \mathrm{~Np}$ & $11 E-02 \pm 2^{(c)}$ & $24 E-02 \pm 5$ & $23 E-02 \pm 7$ & $28 E-02 \pm 5$ & $28 \mathrm{E}-02 \pm 2$ \\
\hline & $46 E-06 \pm 7$ & $48 E-06 \pm 4$ & $254 E-06 \pm 60$ & $273 E-06 \pm 50$ & 310 E-06 \pm 8 \\
\hline $241 \mathrm{Am}$ & $14 E-04 \pm 2$ & $17 E-03 \pm 3$ & $21 E-04 \pm 4$ & $15 E-04 \pm 3$ & $15 E-04 \pm 2$ \\
\hline${ }^{14} \mathrm{Cm}$ & $22 \mathrm{E}-04 \pm 3$ & $12 E-04 \pm 1$ & $42 E-04 \pm 7$ & $15 E-04 \pm 3$ & $14 E-04 \pm 2$ \\
\hline
\end{tabular}

\section{Cheatgrass}

$\begin{array}{lllrrrr}{ }^{237} \mathrm{~Np} & 12 \mathrm{E}-03 \pm 1 & 15 \mathrm{E}-03 \pm 3 & 13 \mathrm{E}-03 \pm 2 & 7 \mathrm{E}-03 \pm 1 & 11 \mathrm{E}-03 \pm 2 \\ { }^{239} \mathrm{Pu} & 17 \mathrm{E}-06 \pm 2 & 14 \mathrm{E}-06 \pm 3 & 43 \mathrm{E}-06 \pm 4 & 53 \mathrm{E}-06 \pm 5 & 51 \mathrm{E}-06 \pm 2 \\ { }^{241} \mathrm{Am} & 60 \mathrm{E}-05 \pm 10 & 23 \mathrm{E}-05 \pm 2 & 8 \mathrm{E}-05 \pm 1 & 6 \mathrm{E}-05 \pm 1 & 10 \mathrm{E}-05 \pm 2 \\ { }^{244} \mathrm{Cm} & 48 \mathrm{E}-05 \pm 5 & 33 \mathrm{E}-05 \pm 3 & 19 \mathrm{E}-05 \pm 2 & 8 \mathrm{E}-05 \pm 1 & 16 \mathrm{E}-05 \pm 1\end{array}$

a. Concentration factor $=\frac{p C i / g \text { plant }}{p C i / g \text { soil }}$

b. Results previously reported in BNWL-1688 $(1)$

c. 11 E-02 \pm 2 equals $11 \times 10^{-2} \pm 2 \times 10^{-2}$ (S.E. mean) 
BNWL -1755

The author is grateful for suggestions provided by T. R. McKenzie, Staff Engineer, Advanced Technology Development Section, ARHCO. 


\section{LITERATURE CITED}

1. Price, K. R. 1972. Uptake of ${ }^{237} \mathrm{~Np},{ }^{239} \mathrm{Pu},{ }^{241} \mathrm{Am}$, and ${ }^{244} \mathrm{Cm}$ from soil by tumbleweed and cheatgrass. USAEC Doc. BNWL-1688. 14 p.

2. Gel'man, A. D., A. I. Moskvin, L. M. Zaitser, and M. D. Mefod'era. 1962. Complex Compounds of Transuranium Elements. Consultants Bureau, New York. (Translation by C. N. and T. I. Turton).

3. Coleman, G. H. 1965. The radiochemistry of plutonium. National Academy of Sciences - National Research Counci1, Wash, D. C.

4. Rhodes, D. W. 1957. Adsorption of plutonium by soil. Soil Sci. $84: 465-471$.

5. Knol1, K. C. 1969. Reaction of organic wastes and soils. USAEC Doc. BNWL-860.

6. Sheidina, L. D. and R. N. Koverskaya. 1969. Colloidal state of $\mathrm{Pu}$ IV in aqueous solutions. Translated from: Radiokhimiya 12:253-259. 
BNWL-1755

Special Distribution

in Category UC-70

\section{DISTRIBUTION}

No. of

Copies

Offsite

1

AEC Chicago Patent Group

G. H. Lee

5 AEC Technical Information Center

Onsite - Hanford

1 AEC Chicago Patent Group

R. W. Poteat

6 AEC Richland Operations Office

P. F. X. Dunnigan, Jr.

0. J. Elgert (2)

E. B. Jackson

W. E. Lotz (2)

25 Atlantic Richfield Hanford Company
M. D. Al ford
L. M. Knights
G. L. Borsheim
D. J. Larson
D. J. Brown
H. L. Maxfield
L. E. Bruns
T. R. McKenzie
M. H. Campbel1
B. J. McMurray
C. A. Colvin
J. V. Panesko
R. P. Corlew
H. P. Shaw
J. B. Fecht
A. E. Smith
G. L. Hanson
P. W. Smith
W. M. Harty
W. P. Ingalls
M. J. Szul inski
R. E. Isaacson
J. H. Warren
G. R. Kiel
R. E. Wheeler

58 Battelle-Northwest
E. L. Alpen
J. P. Corley
J. J. Fuquay
K. R. Price (50)
J. K. Soldat
B. E. Vaughn
Technical Information

2 Douglas United Nuclear

L. V. Barker

C. D. Corbit

2 Westinghouse Hanford

G. D. Carpenter

R. B. Hall 